YEARBOOK
of ANTITRUST
and REGULATORY
STUDIES
www.yars.wz.uw.edu.pl
Peer-reviewed scientific periodical, focusing on legal and economic issues of antitrust and regulation. Creative Commons Attribution-No Derivative Works 3.0 Poland License.

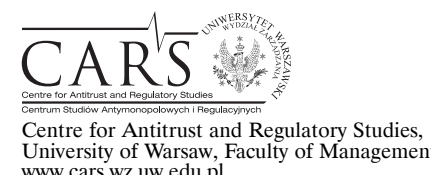

www.cars.wZ.uw.edu.pl

\title{
Legislative Developments in the Aviation Sector in 2010
}

\author{
by
}

\author{
Filip Czernicki*
}

The Polish Aviation Law (in Polish: Prawo Lotnicze; hereafter, PL) of 3 July 2002 was amended only once in 2009 . The amendment was introduced by the Act on the amendment of the Act on the Provision of services on the territory of the Republic of Poland of 4 March 2010 ${ }^{1}$, which entered into force on 10 April 2010. Accordingly, two new provisions were introduced into Polish aviation law: sub-article 1a was inserted into the existing Article 160 PL and a new Article 160a was created. Both insertions specify that the Act on the Provision of services on the territory of the Republic of Poland does not apply to its Aviation Law.

Furthermore, four acts of secondary legislation concerning the aviation sector were issued in 2010 by the Polish Minister of Infrastructure.

First, the executive order dated 18 February $2010^{2}$ confirmed the applicability to Poland of the international requirements set out by the European Organisation for the Safety of Air Navigation (EUROCONTROL) on initial training of air traffic controllers. The executive order established also that specific rules on professional qualifications concerning air traffic controllers will be published by the President of the Polish Civil Aviation Office (in Polish: Urzad Lotnictwa Cywilnego; hereafter, $U L C$ ) in the Polish Civil Aviation Office Law Journal. On the basis of Article 163 PL, a separate executive order will be issued setting out the competences and duties of certified training institutions in this field. These competences and duties will be enforced by the President of the Polish Civil Aviation Office.

Second, the executive order dated 28 April $2010^{3}$ specifies the amount as well as the terms and conditions of money transfers to cover the expenses and

* Filip Czernicki, Analysys' and Projects Section Manager in the Department of Subsidiaries' Supervision, 'Polish Airports' State Enterprise PPL, Plenipotentiary responsible for the creation of the Modlin Airport.

1 Journal of Laws 2010 No. 47, item 278.

2 Journal of Laws 2010 No. 32, item 173.

3 Journal of Laws 2010 No. 75, item 477. 
finance the tasks of the Polish Civil Aviation Office. The amount for the year 2010 was set at 9.828.079 Polish zloty ${ }^{4}$, paid in twelve equal installments. This amount was calculated based on the Order of the European Commission No. 1794/2006 of 6 December 2006 which has set out a common charging scheme for aviation services ${ }^{5}$.

Third, the executive order dated 2 June $2010^{6}$ changed an earlier executive order on special requirements for airstrips. According to the new act, any given airport management authority is required to prepare an airstrip rescue plan. The executive order precisely describes what should such plan consist of, namely:

- basic information about the airstrip, including all technical data;

- general information about aircrafts which are the most common users of the given airstrip;

- alarm instruction and a description of all cooperating units;

- scope of activities which have to be undertaken by the airstrip manager in emergency cases until the arrival of support units;

- description of the rescue and fire fighting protection equipment that is secured while landing, departing, taxing and fueling of aircrafts;

- description of the airstrip, directions of approach and departure zones for flights, emergency landings fields and location of the closest hospitals within $3 \mathrm{~km}$ from the airstrip reference point (as described on the map at a scale of 1:25 000 or bigger).

The plan has to be prepared in cooperation with the local fire brigade which should keep its copy. A copy of the plan has also to be kept at the office of the relevant local authority. The executive order states that airstrips should have at least one access road which connects them with the public roads system. At the time of aircraft landing and departing as well as during fueling, an active means of communication shall be secured at the airstrip.

Forth, the executive order dated 11 June $2010^{7}$ introduces prohibitions and restrictions in air traffic movements in the Polish air space, over the whole country or its parts for a period exceeding three months. The Polish airspace is divided into spheres, a number of special areas among them including: areas D (Danger Area), areas P (Prohibited Area) and areas R (Restricted Area). Certain special air traffic movement conditions are set up for these areas which all air traffic flying during the night (between $22^{00}-6^{00}$ ). The Appendixes present different types of restrictions in refer to: restricted areas, dangerous areas and airspace defense areas.

\footnotetext{
4 App. 2400000 Euro.

5 OJ [2006] L 341/3.

6 Journal of Laws 2010 No. 100, item 640.

7 Journal of Laws 2010 No. 106, item 678.
} 